\title{
Relationship Between Blood and Pericardial Signal Peptide-CUB (complement C1r / C1s, Vegf and Bmp 1) -EGF (epidermal growth factor)-like Protein-1 (SCUBE-1) Levels and Ventricular Functions in Coronary Artery Bypass Patients
}

\author{
Koroner Arter Bypass hastalarında Kan ve Perikardiyal Signal Peptide-CUB \\ (complement C1r / C1s, Vegf and Bmp 1) -EGF (epidermal growth factor)-like \\ Protein-1 (SCUBE-1) Düzeyleri ve Ventrikül Fonksiyonları Arasındaki İlişki
}

\author{
Nazım KANKILIÇ ${ }^{1} \mathbb{D}$, Oğuz KARAHAN ${ }^{2} \mathbb{D}$, Sinan DEMIRTAŞ ${ }^{3} \mathbb{D}^{\mathbb{D}}$, Celal YAVUz ${ }^{4} \mathbb{D}$, \\ Ahmet ÇALIŞKAN ${ }^{5} \mathbb{D}$, Orkut GÜÇLÜ ${ }^{6}$, ibrahim KAPLAN ${ }^{7}$
}

\author{
${ }^{1}$ Medical School of Harran University, Department of Cardiovascular Surgery, Şanlıurfa,TURKEY \\ 2 Medical School of Alanya Alaaddin Keykubat University, Department of Cardiovascular Surgery, Alanya,TURKEY \\ 3 Özel Bower Hospital, Department of Cardiovascular Surgery, Diyarbakır,TURKEY \\ ${ }^{4}$ Medical School of Dicle University, Department of Cardiovascular Surgery, Diyarbakır,TURKEY \\ ${ }^{5}$ Özel Elazığ Medicalpark Hospital, Department of Cardiovascular Surgery, Elazığ,TURKEY \\ ${ }^{6}$ Medical School of Trakya University, Department of Cardiovascular Surgery, Edirne, TURKEY \\ ${ }^{7}$ Medical School of Dicle University, Department of Biochemistry, Diyarbakır,TURKEY
}

\begin{abstract}
Background: Signal peptide-CUB (complement C1r/C1s, Uegf, and Bmp1)-EGF (epidermal growth factor)- like domain- containing protein 1 (SCUBE-1) is a cell surface protein studied as a biomarker in thrombosis and ischemia conditions and secreted at currently studied early embryogenesis. The aim of this study is to investigate the relationship between left ventricular functions and pericardial / serum SCUBE-1 values of patients who underwent coronary artery bypass surgery.

Materials and Methods: Forty patients who underwent cardiopulmonary bypass graft surgery were included in the study. Detailed echocardiographic findings of the patients were made before the operation. Left ventricular dysfunction markers were determined according to left ventricular fracshortening. SCUBE-1 levels were studied with ELISA kits in blood plasma and pericardial fluid samples. SCUBE-1 levels were statistically compared between the determined groups.

Results: Statistical differences were observed in LVDs, IVSd, neutrophil, RBC, CK-MB, troponin-I and WBC values in low and high FS groups $(p<0.05)$. SCUBE-1 plasma levels did not differ statistically between the FS groups $(p>0.05)$. The same situation was similar for pericardial fluid levels $(p>0.05)$. Correlation was seen between SCUBE-1 plasma levels and SCUBE-1 pericardial levels $(p<0.05)$. There was no significant correlation between echocardiographic findings and SCUBE-1 levels ( $p>0.05$ ).

Conclusions: These results showed us that SCUBE-1 plasma and the pericardial fluid levels had no effect on the left ventricular dysfunction. SCUBE-1 is not one of the currently identified markers of cardiac dysfunction. Future studies will further increase our knowledge on this subject.
\end{abstract}

Key Words: SCUBE-1, Coronary artery bypass, Left ventricular functions

öz.

Amaç: Signal peptide-CUB (complement C1r/C1s, Uegf, and Bmp1)-EGF (epidermal growth factor)- like domaincontaining protein 1 (SCUBE-1), tromboz ve iskemi koşullarında biyobelirteç olarak incelenen bir hücre yüzeyi proteinidir ve erken embriyogenezde salgılanmaktadır. Bu çalışmanın amacı, koroner arter baypas ameliyatı geçiren hastaların sol ventrikül fonksiyonları ile perikardiyal / serum SCUBE-1 değerleri arasındaki ilişkiyi araştırmaktır. Materyal ve Metod: Çalışmaya kardiyopulmoner baypas greft cerrahisi uygulanan 40 hasta dahil edildi. Hastaların detaylı ekokardiyografik bulguları operasyon öncesi yapıldı. Sol ventrikül disfonksiyon belirteçleri, sol ventrikül fraksiyonunun kısalmasına (left ventricular fracshortening) (FS) göre belirlendi. SCUBE-1 seviyeleri, kan plazması ve perikardiyal sıvı örneklerinde ELISA kitleri ile çalışıldı. SCUBE-1 seviyeleri belirlenen gruplar arasında istatistiksel olarak karşılaştırıldı.

Bulgular: Düşük ve yüksek FS gruplarında LVDs, IVSd, nötrofil, RBC, CK-MB, troponin-I ve WBC değerlerinde istatistiksel farklılık gözlendi $(p<0,05)$. SCUBE-1 plazma seviyeleri FS grupları arasında istatistiksel olarak farklılık göstermedi ( $p>0.05$ ). Aynı durum perikardiyal SIVı düzeyleri için de benzerdi ( $p>0.05)$. SCUBE-1 plazma seviyeleri ve SCUBE-1 perikardiyal seviyeleri arasında korelasyon görüldü $(p<0,05)$. Ekokardiyografi bulguları ile SCUBE-1 düzeyleri arasında anlamlı korelasyon gözlenmedi ( $p>0.05$ ).

Sonuç: Bu sonuçlar bize SCUBE-1 plazma ve perikardiyal Sıvı seviyelerinin sol ventrikül disfonksiyonu üzerine etkisi olmadığını gösterdi. SCUBE-1, kardiyak disfonksiyonun şu anda tanımlanmış belirteçlerinden biri değildir. Gelecek çalışmalar bu konudaki bilgimizi daha da artıracaktır.

Anahtar kelimeler: SCUBE-1, Koroner arter baypas, Sol ventrikül fonksiyonları

\section{Corresponding Author / Sorumlu Yazar}

Dr. Nazım Kankılıç

Medical School of Harran University, Department of Cardiovascular Surgery, MardinYolu, 63290 Haliliye, Şanlıurfa, TURKEY

\section{E-mail: nfkan82@gmail.com}

Received / Geliş tarihi: 25.08.2021

Accepted / Kabul tarihi: 27.09.2021

DOI: $10.35440 /$ hutfd. 986605

Çalışmanın Yapıldığı Kurum: Dicle Üniversitesi Tıp Fakültesi

*Bu makale Yükseköğretim Kurulu Başkanlığı - Tez Merkezi 424874 numaralı tez yayınından türetilmiştir. Tezin kısa özeti sözlü sunum olarak Türk Kalp ve Damar Cerrahisi Derneği 14. Kongresinde sunulmuştur (Türk Kalp ve Damar Cerrahisi Derneği 14. Kongresi, 3-6 Kasım 2016, Belek, Antalya. [SS-005] ). 


\section{Introduction}

Atherosclerosis is a systematic disease stemming from deterioration of important tissues due to the distortion of blood flux resulting in significant clinical results (1). The first visible information for atherosclerosis is the accumulation of fat deposits in tunica intima starting at an early age. The increased formation of fatty streaks leads to endothelial dysfunction which is an early determiner of atherosclerosis and has a major role in the development of atherosclerosis. Furthermore, it's a fixable and preventable pathology, and early diagnosis and treatment are significant to preventing the irreversible effects of arterial occlusion $(1,2)$.

SCUBE-1 [signal peptide-CUB (complement C1r/C1s, Uegf, and Bmp1)-EGF (epidermal growth factor)-like domaincontaining protein 1] is a newly discovered cell surface molecule, secreted from cell surfaces in early embryogenesis (3). Gene synthesizing SCUBE-1 in the mouse genome is mapped at chromosome 15. It is isolated to be revealed at the 22q13 synthetic area in the human genome (4). SCUBE genes were shown in early embryogenesis, where they emerged in some tissue groups in mice: the gonads, central nervous system, dermomyotome, mesenchyme tissue, and organ buds. SCUBE-1 also emerged from endothelial and platelet cells during embryonic development (3). That is why SCUBE-1 and SCUBE-2 are defined as proteins emerged by being secreted from the human gene family, expressed from the vascular endothelium playing a significant role in inflammatory and thrombosis (5). SCUBE-1 was immunohistochemically shown to be gathering in the atheroma plaque in the sub-endothelial matrix (6). Moreover, SCUBE1 proteins were exposed to be stored on stimulated and activated platelets and alpha granules with immune localized techniques (7). Following the activation of thrombin, they help the thrombus gather by translocating toward the thrombocyte surface as small soluble particles. The SCUBE1 protein was detected as "non-sensitive" within the first 6 hours in ischemic process. This led to the idea that SCUBE1 could be a very good marker in acute thrombotic diseases (6) as a new "early platelet endothelium adhesion molecule". Important studies are now being conducted in regards to the prevention of the irreversible effects of endothelial dysfunction and arterial occlusion and possibly help early diagnosis and treatment.

The aim of this study is to investigate SCUBE-1 levels in coronary artery bypass patients and to determine the effect of SCUBE-1 on left ventricular functions [left ventricular fractional shortening rate (\%) (FS)].

\section{Materials and Methods}

\section{Patient Selection}

Patients who accepted to participate investigation were included in the study. Patients with systemic inflammatory diseases (diabetes excluded), peripheral arterial and venous diseases, patients with an active infection, recurrent/emergency cardiac surgery, obesity, very low ejection fraction ( $25 \%$ or less), severe pericardial effusion, and patients with a previous benign or malignant pathology were excluded from the study. Totally forty individuals included in the study, and demographical variables, echocardiographic measurements, and blood tests were recorded prospectively.

\section{Ethics}

The study was conducted with data retrieved between 2014 and 2015 and was approved by local ethical committee [(This study was approved by the Dicle University Medical Faculty Ethics Committee for Noninterventional Studies (Meeting number: 25.02.2013/28)]. All steps of this prospectively designed study were planned in accordance with the Helsinki Declaration. All participants received a voluntary approval form.

\section{Transthoracic Echocardiography Measurements}

Transthoracic echocardiography of all patients included in this study was taken preoperatively with a broadband echocardiography device (Vivid S6, GE Vingmed Ultrasound, Horten, Norway). Measurements were retrieved by long axis and apical 4 spaces with standard criteria. Fractional shortening (FS) is a measure of left ventricular (LV) contraction calculated using changes in LV cavity dimensions (8). The normal range of FS is $25 \%-45 \%(25 \%-43 \%$ in men and $27 \%$ - $45 \%$ in women) (9). Preoperational values of left ventricular fractional shortening rate (\%) (FS) [(FS= Left Ventricular end-diastolic dimension (cm) (LVDd) - Left Ventricular end-systolic dimension (cm) (LVDs)/ Left Ventricular end-diastolic dimension (cm) (LVDd) x 100\%)] $(8,10)$ were calculated. All echocardiography measurements were recorded. Cardiac performances of the patients were grouped by $\mathrm{FS}$ frequency (high $\mathrm{FS} \geq 33 \%$ and low $\mathrm{FS}<33 \%$ ). Left ventricular dysfunction criteria were determined as low FS (<33\%) (11).

Blood and Pericardial Fluid Sample Measurements Just before anesthetic induction, blood gas was taken during the arterial blood gas sampling control, and following the sternotomy, blood inlet was prevented by forming a small aperture in the pericardium, and pericardium liquid was taken (at least $2 \mathrm{ml}$ ) (cases where blood inlet into the pericardial fluid occurred were excluded from the study). Arterial blood samples taken before the operation and pericardial fluids taken during the operation were placed into jelled biochemistry tubes. Blood samples were processed by centrifuging at 4000 RPM for 5 min to have plasma samples. Later on, samples of pericardial fluid and blood plasma were stored in Eppendorf tubes at $-80^{\circ} \mathrm{C}$. Measurements of SCUBE-1 were conducted in accordance with the method put forward by Türkmen et al. (12).

Measurements were conducted using Human Signal short protein sequence, CUB EGF-like domain-containing protein 1 (SCUBE-1) Enzyme-linked immunosorbent assay test Kit. (Catalog number: CK-E90466, EASTBIO CO., LTD. 5F, MORITA BLDG., 2-4-6 BINGOMACHI, CHUO-KU, OSAKA, 541-0051, JAPAN). The lowest measurable dose was identified by the results as $0.16 \mathrm{ng} / \mathrm{dL}$. Results were recorded as 
$\mathrm{ng} / \mathrm{dL}$ units.

\section{Statistical Analysis}

Statistical analyses were conducted with SPSS for Windows version 18.0 software (IBM SPSS Inc, Chicago, IL, USA). The normal distribution was determined by Kolmogorov Smirnov test. Numerical variables with normal distribution were presented as mean \pm standard deviation, while those without normal distribution were expressed as median (min-max) values. The categorical variables were expressed as $n(\%)$. Comparison of two-sample numerical variables was conducted using the Unpaired Student's t-test and Mann-Whitney $U$ test. Chi-Square test was used to determine the difference between groups of categorical variables. The Pearson correlation test was used for correlation analysis. The confidence interval $(\mathrm{Cl})$ was accepted as $95 \%$ throughout the analyses. A two-tailed $p$ value of $<0.05$ was considered statistically significant.

\section{Results}

The mean age of the patients was $63,19 \pm 9,74$ in FS $<33 \%$ group and $60,42 \pm 7,85$ in FS> 33\% group. Ages were found to be similar in all groups. Groups were compared in terms of age, smoking, diabetes mellitus and hypertension in Table-1.

Table 1.Comparison of main characteristic between groups.

\begin{tabular}{|c|c|c|c|}
\hline & \multicolumn{2}{|c|}{ FS group } & \multirow[b]{2}{*}{$\mathbf{p}$} \\
\hline & $\begin{array}{c}\mathrm{FS}<\% 33 \\
(\mathrm{n}: 21)\end{array}$ & $\begin{array}{c}\text { FS }>\% 33 \\
\text { (n:19) }\end{array}$ & \\
\hline \multicolumn{3}{|l|}{ Gender } & \multirow{3}{*}{0,583} \\
\hline \begin{tabular}{l|l} 
& Female \\
\end{tabular} & $5(\% 23,8)$ & $6(\% 31,6)$ & \\
\hline Male & $16(\% 76,2)$ & $13(\% 68,4)$ & \\
\hline \multicolumn{3}{|l|}{ Smoking } & \multirow{3}{*}{0,141} \\
\hline \begin{tabular}{l|l} 
Absent \\
\end{tabular} & $12(\% 57,1)$ & $15(\% 78,9)$ & \\
\hline Present & $9(\% 42,9)$ & $4(\% 21,1)$ & \\
\hline \multicolumn{3}{|l|}{ Hypertension } & \multirow{3}{*}{0,536} \\
\hline Absent & $12(\% 57,1)$ & $9(\% 47,4)$ & \\
\hline Present & $9(\% 42,9)$ & $10(\% 52,6)$ & \\
\hline \multicolumn{3}{|c|}{ Diabetes mellitus } & \multirow{3}{*}{0,462} \\
\hline Absent & $12(\% 57,1)$ & $13(\% 68,4)$ & \\
\hline Present & $9(\% 42,9)$ & $6(\% 31,6)$ & \\
\hline
\end{tabular}

FS: Left Ventricular Fractshortening

The mean (min-max) FS (\%) was 28 (14-33) in FS< 33\% group and 38 (34-45) FS> 33\% group. A significant difference was observed in Left ventricular internal dimensions at end systole (LVDs) ( $p: 0,007)$, interventricular septum at end diastole (IVSd) ( $p$ : 0,019), red blood cell (RBC) ( $p$ : $0,045)$, white blood cell (WBC) ( $p: 0,004)$, neutrophil ( $p$ : $0,006), \mathrm{CK}-\mathrm{MB}(p: 0,022)$ and troponin-I $(p: 0,037)$ between FS groups. RBC, WBC, neutrophil, CK-MB and troponin-I values were found to be high at low FS values. There was no significant difference on both SCUBE-1 levels in the FS groups ( $p>0.05$ ) (Figure-1 and Figure-2).

Comparisons of echocardiography findings, blood values and SCUBE- 1 levels are summarized in Table-2. In correlation analyzes positive correlation was seen between
SCUBE-1 plasma levels and SCUBE-1 pericardial levels ( $p$ $<0.05$ ) (Figure-3). There was no correlation between echocardiography findings and SCUBE-1 levels ( $p>0.05)$. Correlation analyses are shown in Table-3

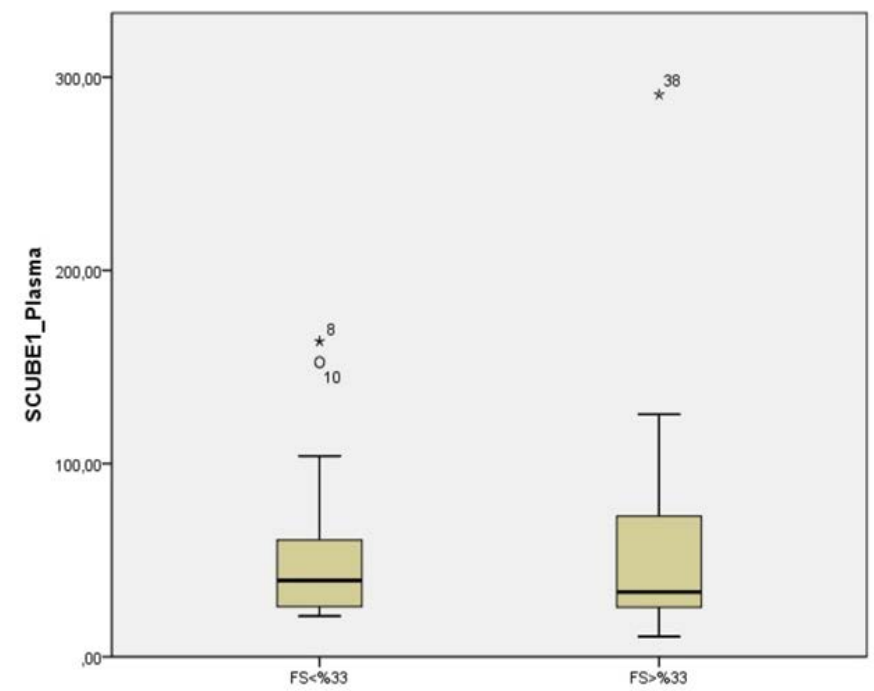

Figure 1. Box-plot graphic of Plasma SCUBE-1 levels between FS (Left Ventricular Fractshortening) Groups

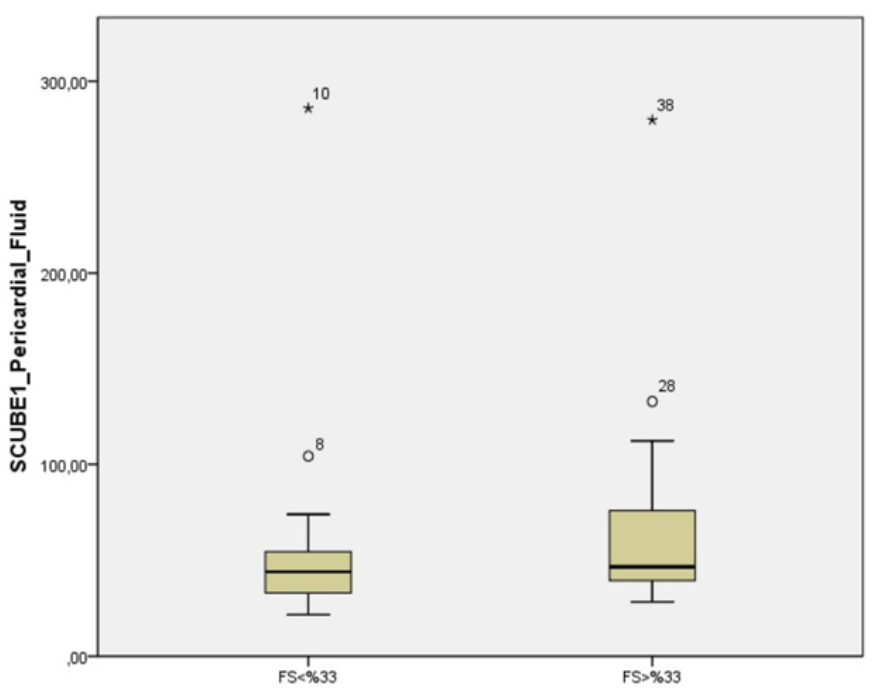

Figure 2. Box-plot graphic of Pericardial Fluid SCUBE-1 levels between FS (Left Ventricular Fractshortening) Groups

\section{Discussion}

SCUBE-1 has been studied in many diseases $(13,14)$. With the studies carried out, more information was gathered about its properties and effectiveness (15). Increased SCUBE-1 plasma levels, especially in endothelial and thrombocyte-induced thrombosis, showed that this molecule could be very important in vascular dysfunction. Studies have shown increased plasma SCUBE-1 levels correlation with the increased nitric oxide (NO) in endothelial response resulting from endothelial damage and ischemia (16). 
Table 2.Comparison of Echocardiography findings, blood values and SCUBE-1 levels between groups

\begin{tabular}{|c|c|c|c|}
\hline & & oup & \\
\hline & $\begin{array}{c}\mathrm{FS}<\% 33 \\
(\mathrm{n}: 21)\end{array}$ & $\begin{array}{c}F S>\% 33 \\
(n: 19)\end{array}$ & $\mathbf{p}^{*}$ \\
\hline Age (at diagnosis) & $63,19 \pm 9,74$ & $60,42 \pm 7,85$ & 0,254 \\
\hline HCT (\%) & $41,06 \pm 4,80$ & $39,24 \pm 4,016$ & 0,250 \\
\hline $\operatorname{RBC}\left(\times 10^{3} / \mathrm{mm}^{3}\right)$ & $5,04(3,92-5,7)$ & $4,72(2,78-5,47)$ & 0,045 \\
\hline Hemoglobin $(\mathrm{g} / \mathrm{dL})$ & $13,54(10-16,2)$ & $12,8(9,72-14,87)$ & 0,357 \\
\hline Neutrophil $\left(\times 10^{3} / \mathrm{mm}^{3}\right)$ & $5,65 \pm 0,95$ & $4,86 \pm 1,54$ & 0,006 \\
\hline Lymphocyte $\left(\times 10^{3} / \mathrm{mm}^{3}\right)$ & $2,45(1,02-6,34)$ & $2,03(1,19-3,13)$ & 0,323 \\
\hline $\operatorname{PLT}\left(\times 10^{3} / \mathrm{mm}^{3}\right)$ & $252,75 \pm 63,85$ & $227,94 \pm 51,06$ & 0,218 \\
\hline NLR & $2,85(0,78-7,01)$ & $2,47(1,38-4,25)$ & 0,755 \\
\hline White Blood Cell $\left(\times 10^{3} / \mathrm{mm}^{3}\right)$ & $9,05(6,01-12,3)$ & $7,70(4,92-12,8)$ & 0,004 \\
\hline Albumin $(\mathrm{g} / \mathrm{dL})$ & $3,41 \pm 0,56$ & $3,53 \pm 0,27$ & 0,946 \\
\hline Urea(g/dL) & $38,66(26-73)$ & $37,42(23-60)$ & 1,000 \\
\hline Creatinine $(\mathrm{g} / \mathrm{dL})$ & $0,95(0,73-2,33)$ & $0,92(0,69-1,63)$ & 0,903 \\
\hline $\operatorname{ALT}(U / L)$ & $22,57(9-55)$ & $34,3(7-91)$ & 0,272 \\
\hline Triglyceride (mg/dL) & $225,6(63-721)$ & $205,5(50-447)$ & 0,882 \\
\hline Cholesterol(mg/dL) & $191,7 \pm 48,14$ & $167,9 \pm 44,2$ & 0,101 \\
\hline HDL (High-density lipoprotein) (mg/dL) & $32,90 \pm 8,23$ & $28,89 \pm 6,61$ & 0,162 \\
\hline LDL(Low-density lipoprotein) (mg/dL) & $144(38,6-400)$ & $128(21,6-400)$ & 0,316 \\
\hline CK_MB(ng/mL) & $8,42(0,8-93,6)$ & $1,76(0-5,3)$ & 0,022 \\
\hline Troponin_l(ng/mL) & $3,17(0,001-40,3)$ & $0,104(0,001-0,61)$ & 0,037 \\
\hline LV end-diastolic diameter (cm) (LVDd) & $4,63 \pm 0,65$ & $4,81 \pm 0,39$ & 0,472 \\
\hline LV end-systolic diameter (cm) (LVDs) & $3,34 \pm 0,62$ & $2,96 \pm 0,22$ & 0,007 \\
\hline Interventricular septum (cm) (IVSd) & $1,21(0,9-1,5)$ & $1,12(0,8-1,9)$ & 0,019 \\
\hline Fractional shortening (\%) & $28(14-33)$ & $38(34-45)$ & $<0.001$ \\
\hline SCUBE 1 PLASMA (SERUM)* (ng/dL) & $53,54(21,1-163)$ & $59,87(10,4-290)$ & 0,715 \\
\hline SCUBE 1 PERICARDIAL FLUID* (ng/dL) & $58,47(21,7-285)$ & $68,64(28,4-279)$ & 0,291 \\
\hline
\end{tabular}

FS: Left Ventricular Fractshortening, HCT: Hematocrit, PLT: Platelet, ALT: Alanin Aminotransferaz, RBC: Red Blood Cell, NLR: Neutrophil/Lymphocyte Ratio

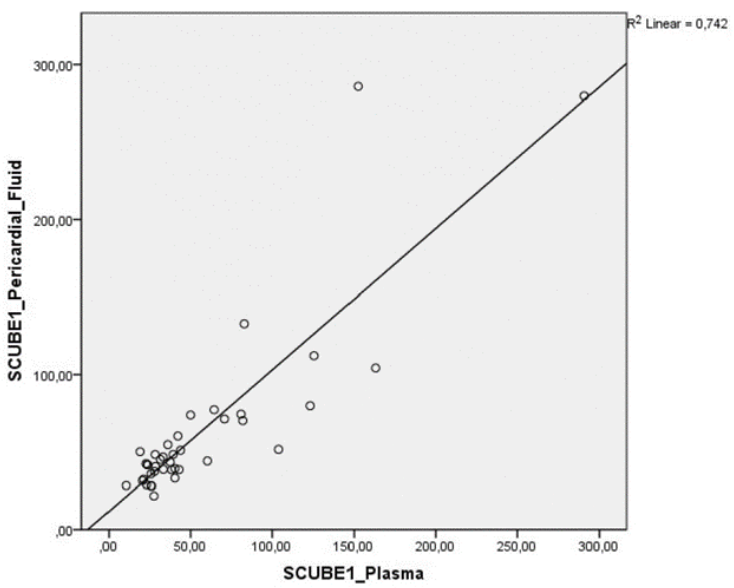

Figure 3. Correlation between SCUBE-1 plasma and pericardial fluid levels.

It has gained a different dimension with the determination of SCUBE-1 in atherosclerotic plaques. According to Sonmez et al, SCUBE-1 has been shown to be useful in the differentiation of non- ST elevation myocardial infarct (NSTE) and non-cardiac chest pain (NCCP) patients (17). Similarly, increased plasma SCUBE-1 levels were shown in experimental mesenteric ischemia, acute coronary syndrome, and acute ischemic stroke $(6,12)$. On the contrary, it is stated in some studies that SCUBE-1 levels may not be very useful in the early diagnosis of acute ischemic stroke (18). With all its known properties, SCUBE-1 is one of the first molecules thought to be effective on cardiac damage and cardiac remodeling. To the best of our knowledge, there are very few studies in the literature investigating the relationship between ventricular functions and SCUBE-1 (19).

Table 3. Correlation analyses between SCUBE-1 plasma /SCUBE-1 Pericardial Fluid levels and echocardiography measurements.

\begin{tabular}{|l|l|c|c|c|c|c|c|}
\hline & & $\begin{array}{c}\text { Fractional } \\
\text { shortening } \\
\text { (FS) }\end{array}$ & LVDd & LVDs & IVSD & LAD & RAD \\
\hline $\begin{array}{l}\text { SCUBE-1 } \\
\text { Plasma (ng/dL) }\end{array}$ & $r$ - Values & 0,149 & 0,122 & $-0,017$ & $-0,112$ & $-0,035$ & $-0,263$ \\
\cline { 2 - 8 } & $\boldsymbol{p}$ - Values & 0,359 & 0,453 & 0,916 & 0,493 & 0,835 & 0,291 \\
\hline $\begin{array}{l}\text { SCUBE-1 } \\
\text { Pericardial Fluid } \\
\text { Inr/dII }\end{array}$ & $r$ - Values & 0,164 & 0,150 & $-0,006$ & $-0,177$ & $-0,038$ & $-0,260$ \\
\cline { 2 - 8 } & $p$ - Values & 0,313 & 0,355 & 0,970 & 0,276 & 0,821 & 0,296 \\
\hline
\end{tabular}

IVSD: interventricular septum at end diastole

LVDd: Left ventricular internal dimensions at end diastole LVDs: Left ventricular internal dimensions at end systole LAD: Left atrial dimensions

RAD: Right atrial dimensions

Ventricular dysfunction caused by endothelial dysfunction and myocardial damage causes pericardial fluid increase. Although not fully understood, the increase in pericardial fluid is thought to be associated with raised right atrial pressures, which cannot be prevented in patients with low ejection fraction (20). It has been shown that some biomarkers increased serum and pericardial fluid in patients 
with left ventricular diastolic dysfunction (21-23). We studied SCUBE-1 levels both plasma and pericardial fluid samples. To our knowledge, this is the first (albeit preliminary) study to investigate the SCUBE-1 levels in pericardial fluid. In our study, SCUBE-1 (in both plasma and pericardial fluid samples) levels did not differ in patients with left ventricular dysfunction. Similar findings are supported by a recent study in renal transplant patients (19). There may be several reasons for this. The first is that SCUBE-1 was shown to increase in acute ischemic events, especially in the first 6 hours (6), and the patient group included in our study did not have acute ischemic conditions. Secondly, SCUBE-1 has been shown in atherosclerotic plaque formation but it shows its main activity through activated platelets, platelet adhesion and agglutination. The role of SCUBE-1 in the atherosclerosis process still remains unclear (24). In addition, SCUBE-1 is expressed only in endothelial cells and platelets in humans. In contrast, SCUBE-2, another member of the SCUBE family, is expressed in many tissues, including cardiovascular tissues, and is thought to have higher cardiovascular activity (25). The fact that SCUBE-1 is not expressed in cardiac tissues may explain that it has no effect on cardiac dysfunction and cardiac remodeling and does not significantly increase in plasma and pericardial fluid.

There are some limitations to this study. The first one is the low number of patients participating in our research. Secondly, healthy adult groups were not included in the study for comparison of plasma SCUBE-1 levels, and last but not least, SCUBE-1 levels could not be investigated histopathologically on pericardial tissue samples.

\section{Conclusion}

Our study showed that plasma and pericardial fluid levels of SCUBE-1, which is associated with endothelial dysfunction, had no effect on left ventricular dysfunction. Known cardiac biomarkers and inflammatory markers were thought to be more effective than SCUBE-1 on left ventricular functions. Further studies on the SCUBE gene family will increase our knowledge and explain the functions of these molecules more clearly.

Ethical Approval: This study was approved by the Dicle University Medical Faculty Ethics Committee For Noninterventional Studies (Meeting number: 25.02.2013/28)

\author{
Author Contributions: \\ Concept: N.K., O.K. \\ Literature Review: N.K., O.K., S.D. \\ Design : N.K., O.K., S.D. \\ Data acquisition: N.K., O.K., O.G., I.K. \\ Analysis and interpretation: N.K., O.K., S.D., C.Y., A.Ç. \\ Writing manuscript: N.K., O.K. \\ Critical revision of manuscript: O.K., S.D.
}

Conflict of Interest: The authors have no conflicts of interest to declare.

Financial Disclosure: Authors declared no financial support.

\section{References}

1. Javanmard SH, Nematbakhsh M, Sanei MH. Early prevention by L-Arginine attenuates coronary atherosclerosis in a model of hypercholesterolemic animals; no positive results for treatment. Nutr Metab (Lond). 2009; 6:13. doi: 10.1186/1743-7075-6-13.

2. Davignon J, Ganz P. Role of endothelial dysfunction in atherosclerosis. Circulation. 2004; 109 (23 Suppl 1): III27-32. doi:10.1161/01. CIR. 0000131515.03336.f8.

3. Tu CF, Yan YT, Wu SY, Djoko B, Tsai MT, Cheng CJ, et al. Domain and functional analysis of a novel platelet-endothelial cell surface protein, SCUBE1. J Biol Chem. 2008; 283(18):12478-88. doi: 10.1074/jbc.M705872200.

4. Grimmond S, Larder R, Van Hateren N, P Siggers, T J Hulsebos, R Arkell et al. Cloning, mapping, and expression analysis of a gene encoding a novel mammalian EGF-related protein (SCUBE1). Genomics. 2000; 70(1):74-81. doi:10.1006/geno.2000.6370.

5. Yang RB, Ng Domingos CK, Wasserman SM, Colman SD, Shenoy S, Mehraban F, et al. Identification of a novel family of cell-surface proteins expressed in human vascular endothelium. J Biol Chem. 2002; 277(48):46364-73. doi: 10.1074/jbc.M207410200.

6. Dai DF, Thajeb P, Tu CF, Chiang FT, Chen $\mathrm{CH}$, Yang RB, et al. Plasma concentration of SCUBE1, a novel platelet protein, is elevated in patients with acute coronary syndrome and ischemic stroke. J Am Coll Cardiol. 2008; 51(22):217380. doi: 10.1016/j.jacc.2008.01.060.

7. Tu CF, Su YH, Huang YN, Tsai MT, Li LT, Chen YL, et al. Localization and characterization of a novel secreted protein SCUBE1 in human platelets. Cardiovasc Res. 2006; 71(3):486-95. doi: 10.1016/j.cardiores.2006.04.010.

8. G de Simone, R B Devereux, M J Roman, A Ganau, P S Saba, $\mathrm{M} \mathrm{H}$ Alderman, et al. Assessment of left ventricular function by the midwall fractional shortening/end-systolic stress relation in human hypertension. J Am Coll Cardiol. 1994; 23(6):1444-51. doi: 10.1016/0735-1097(94)903905.

9. Lang RM, Goldstein SA, Kronzon I, Khanderia BK, Mor-Avi V. ASE's Comprehensive Echocardiography. 2nd Edition. Elsevier. 2016. p.p113. 113-138. ISBN : 9780323698306

10. Lang RM, Bierig M, Devereux RB, Flachskampf FA, Foster E, Pellikka PA, et al. Recommendations for chamber quantification: a report from the American Society of Echocardiography's Guidelines and Standards Committee and the Chamber Quantification Writing Group, developed in conjunction with the European Association of Echocardiography, a branch of the European Society of Cardiology. J Am Soc Echocardiogr. 2005; 18(12):1440-63. doi: 10.1016/j.echo.2005.10.005.

11. Orvin K, Herzberg H, Golovchiner G, Kadmon E, Omelchenko A, et al. Relation of Left Ventricular Fractional Shortening to Need for Permanent Pacemaker After Transcatheter Aortic Valve Implantation. Am J Cardiol. 2018; 122(5):833-837. doi: 10.1016/j.amjcard.2018.05.029.

12. Turkmen $S$, Mentese $S$, Mentese A, Sumer AU, Saglam $K$, Yulug $E$, et al. The value of signal peptide-CUB-EGF domain-containing protein 1 and oxidative stress parameters in the diagnosis of acute mesenteric ischemia. Acad Emerg Med. 2013; 20(3):257-64. doi: 10.1111/acem.12096.

13. Icel E, Icel A, Mertoglu C, Tasli NG, Karakurt $Y$, Ucak T, et 
al. Serum SCUBE-1 levels in patients with diabetic retinopathy. Int Ophthalmol. 2020; 40(4):859-865. doi: 10.1007/s10792-019-01249-8.

14. Gündüz I, Batmaz I, Bozan T, Ekinci A, Cevik R. The relationship of serum SCUBE-1, -2 and -3 levels with clinical findings and ultrasonographic skin thickness in systemic sclerosis patients. Int J Rheum Dis. 2020; 23(4):526-531.doi: 10.1111/1756-185X.13798.

15. Lindemann S, Gawaz M. SCUBE1--a new scoop in vascular biology? Cardiovasc Res. 2006; 71(3):414-5.doi: 10.1016/j.cardiores.2006.06.005.

16. Etli M, Karahan O. Serum SCUBE-1 levels can predict endothelial dysfunction in healthy young adults. Turkish Journal of Vascular Surgery. 2019; 28(1):31-35. doi: 10.9739/tjvs.2019.299

17. Sonmez E, Turkdogan KA, Karabacak M, Civelek C, Yilmaz $C$, Ozer OF, et al. The diagnostic role of signal peptide$\mathrm{C} 1 \mathrm{r} / \mathrm{C} 1 \mathrm{~s}$, Uegf, and Bmp1-epidermal growth factor domain-containing protein 1 in non-ST-elevation acute coronary syndrome. Am J Emerg Med. 2015; 33(1):21-4. doi: 10.1016/j.ajem.2014.09.047.

18. Mücahit $G$, Süha $T$, Aynur $S$, Sümer $A$, Menteşe $A$, Türedi $S$, et al. The diagnostic value of SCUBE1 levels in acute ischemic Stroke. Türk Biyokimya Dergisi [Turkish Journal of Biochemistry-Turk J Biochem]. 2014; 39 (1) ;107-112. doi: 10.5505/tjb.2014.43534

19. Ayan H, Akilli R, Kaya B, Paydas S, Kara E, Cureoglu A. Relationship Between SCUBE1 Levels and Echocardiography and Electrocardiography Findings and Epicardial Adipose Tissue/Carotid Intima-Media Thickness in Patients Receiving Renal Replacement Therapy. Exp Clin Transplant. 2019; 17 (Suppl 1):181-187. doi: 10.6002/ect.MESOT2018.P58.

20. Raymond RJ, Hinderliter AL, Willis PW, Ralph D, Caldwell EJ, Williams W, et al. Echocardiographic predictors of adverse outcomes in primary pulmonary hypertension. J Am Coll Cardiol. 2002; 39(7):1214-9. doi: 10.1016/s07351097(02)01744-8.

21. Watanabe M, Kawaguchi $S$, Nakahara $H$, Hachimaru T. The roles of natriuretic peptides in pericardial fluid in patients with heart failure. Clin Cardiol. 2009; 32(3):159-63. doi:10.1002/clc.20306.

22. Guclu O, Karahan O, Karabacak M, Yuksel V, Huseyin S, Mavitas B. Evaluation of Pericardial Fluid CType Natriuretic Peptide Levels in Patients Undergoing Coronary Bypass Surgery. Thorac Cardiovasc Surg. 2017; 65(4):311-314. doi: 10.1055/s-0036-1579626.

23. Zhu BL, Ishikawa $T$, Michiue $T$, Li DR, Zhao D, Kamikodai $Y$, et al. Postmortem cardiac troponin $t$ levels in the blood and pericardial fluid. Part 2: Analysis for application in the diagnosis of sudden cardiac death with regard to pathology. Leg Med (Tokyo). 2006; 8(2):94-101. doi: 10.1016/j.legalmed.2005.10.003.

24. Ali H, Emoto N, Yagi K, Vignon-Zellweger N, Nakayama K, Hatakeyama $\mathrm{K}$, et al. Localization and characterization of a novel secreted protein, SCUBE2, in the development and progression of atherosclerosis. Kobe J Med Sci. 2013; 59(4):E122-31. PMID: 24598273

25. Xavier GM, Cobourne MT. SCUBE2 expression extends beyond the central nervous system during mouse development. J Mol Histol. 2011; 42(5):383-91. doi: 10.1007/s10735-011-9341-7. 